\title{
Experience of persons with epilepsy in labour market
}

\author{
Jolanta Pivoriene ${ }^{1, *}$ and Polina Sediene ${ }^{2}$ \\ ${ }^{1}$ Mykolas Romeris University, Vilnius, Lithuania \\ ${ }^{2}$ Lithuanian University of Health Sciences, Kaunas, Lithuania
}

\begin{abstract}
The goal of the article is to reveal how the right to work is implemented regarding persons with epilepsy by investigating their subjective experience. The article is based on qualitative research methodology. By using content analysis three categories with subcategories were formulated: motivation (high motivation for employment, demotivating factors), experience in labour market (negative emotions during job interview, hiding the illness, consequences of hiding the illness, stress for possible seizure at work), relations with employers (expectations toward employers, stigmatized attitude of employers, stereotypical thinking). Research data shows that persons with epilepsy have high motivation in searching job and attempting to stay in labour market, because they want financial stability, safety and inclusion in social life. The main demotivating factors are painful experience during job interviews; not adjusted working conditions and environment. Persons with epilepsy experience negative emotions during job interviews, they hide their illness from employers as long as it is possible, but even after illness is discovered they constantly feel stress for possible seizure. Research participants have clear and specific expectations, they feel stigmatized, stereotypical attitudes to them, and want individualized approach to the situation, and adjustment of working conditions to their abilities.
\end{abstract}

Key words: right to work, persons with epilepsy, labour market.

\section{Introduction}

Epilepsy is one of the most prevalent neurological disorders. It could affect any person no matter their age, gender, origin or other factors. According to Health Information Centre at Hygiene Institute data the number of people with epilepsy has raised by $13 \%$ since 2010 . However, there is no exact statistical data as number of persons with epilepsy includes those only who have disability determined by medical authorities [1]. There is no necessary assessment, rehabilitation model, support system for persons with epilepsy [2]. This illness is surrounded by fear and mystery; persons with epilepsy find difficulties in leading meaningful social life. Job is one of the most important elements in human life leading to self-realization, safety and stability. A working person is valuable first of all for him/herself and then for his/her near environment, community and society [3]. The right to work is inscribed in the main national [4] and international documents [5]. However, there is very little data about how this right is actually implemented. Majority of researches on epilepsy are conducted in the field of medicine [6], there are only few investigations in social life of persons with

\footnotetext{
* Corresponding author: jolantapiv@mruni.eu
}

(C) The Authors, published by EDP Sciences. This is an Open Access article distributed under the terms of the Creative Commons Attribution License 4.0 (http://creativecommons.org/licenses/by/4.0/). 
epilepsy. Sediene and Pivoriene have analysed theoretical aspects of epilepsy in the light of classical sociological [7] and existential [8] theories; Butvilas, Krisciunas, Endziniene, Jurkeviciene and Svedaite-Sakalauske [9] questioned about fullness of life; Krutuliene, Bagdonas, Jakutiene and Zdanaviciute [10] researched psychosocial situation; Jurkuvenas, Mameniskiene and Bagdonas [11] - personal characteristics; Krutuliene [12] - quality of life; Ambramaviciens ir Aleksiene [13] - social inclusions using music therapy; Krutuliene [14] - traits of political, cultural and social participation.

The researches on situation of persons with epilepsy in the labour market are even more limited $[15,16]$. Given the relevance of the problem and the lack of research the goal of the study is to find out how the right to work for people with epilepsy is exercised, investigating their subjective work experience. Object - work experience of persons with epilepsy. The article is based on qualitative research methodology using interview as data collecting technique. Selection criteria for research participants were: diagnosis of epilepsy, illness seizures, working age, and experience in labour market. Data of five research participants is included in qualitative content analysis. Three categories with subcategories are formulated: motivation (high motivation for employment, demotivating factors), experience in labour market (negative emotions during job interview, hiding the illness, consequences of hiding the illness, stress for possible seizure at work), relations with employees (expectations toward employees, stigmatized attitude of employees, stereotypical thinking). For ethical reasons depersonalised data is presented in the article. The main limitation of the research is that due to interview translations from Lithuania to English language the validity could be lessen.

\section{Psychosocial definition of epilepsy and possibilities for coping with psychosocial consequences of epilepsy}

Classical sociological theories analyse changing social roles of persons with illness, interactions between society and a person with new roles, stigmatization processes, acceptance or rejections. In the general context of health and illness, chronic illness is investigated as a specific research object. Epilepsy is one of the chronic illnesses which are in the field of sociological interest. Epilepsy in the light of classical sociological theories is analysed by describing changes of social roles, role of the society in forming social identity of a person with epilepsy, labelling and stigmatization. Big emphasis is put on how symbolic meanings are related to epilepsy and what are social consequences of the illness. A person and a society attach such meanings to epilepsy which enforce labelling and stigmatisation leading to stronger negative social consequences of the illness. Present and future social interactions are weakened and inclusion of persons with epilepsy to the society is diminished [17].

Understanding of epilepsy and its psychosocial consequences is complex and ambiguous. Attitudes toward persons with epilepsy depend on historical, psychosocial and medical understanding of the illness. This illness is invisible therefore is mystified and full of myth, which raises tension in dealing with persons with epilepsy. Historical cultural context of epilepsy presupposes attitude that epileptic seizure is "an awful" event, encounter with death, which reminds finality of human, event which causes fear, panic, rejection of surrenders and which restrains social life of person with epilepsy, his/her self-perception. Therefore people with epilepsy very often confine themselves in a sick person's role, isolate themselves from society, and become dependent on others [18].

Bio-psychosocial consequences of the illness have no direct relation with the process of illness in the current moment, but rather are connected with fear that a seizure could happen in the future. Negative attitudes of the society also interfere with lives of persons with epilepsy [19, 20]. 
It is proven that epilepsy affects all areas of person's life: personal development, interpersonal relations, friendships, marriage, family life, education, employment, etc. [21]. Persons with epilepsy very often lead an excluded life, have low self-esteem, they are stigmatized, prone to depression, have fears, are not motivated to study or work, have communication difficulties [22]. Education level of persons with epilepsy is lower in comparison with persons without epilepsy due to medical (side effects of medicines, repeated seizures, memory disorders) and psychosocial (disappointment, fears, hyper-care, restrictions in environment) reasons [23]. Research data shows that employment is one of the biggest problems for persons with epilepsy; every third respondent defined the problem as very important [24]. Very often these persons do not work, not because of health problems or incapacity to complete the tasks at work, but because of low motivation and negative attitudes to the illness by employers and persons with epilepsy themselves [25]. Krutuliene [26] agrees that employment is one of the most challenging problems and also it is one of the most stigmatized areas in the life of persons with epilepsy. Stigma could be diminished by providing more information on epilepsy, seizures, and suggestions how to behave during seizures [27]. It is necessary to reduce negative attitudes to persons with epilepsy by constantly educating society [28].

\section{Experience of persons with epilepsy}

In the category "Motivation" the following subcategories were formulated: high motivation for employment and demotivating factors.

Motivation very often is related with financial and social challenges. Research participants revealed what motivates them to search for a job:

"It is very difficult emotionally. You know that you live not in your own flat; you know that you need to put your children in bed at nine o'clock and can't even read or do anything because there is only one room and light would trouble children. I fall asleep only at twelve, so everything is burning in my head" (I interview).

"I wish, I really could cope with all these elementary things. Job. Family. Everything like that" (V interview).

Most of persons with epilepsy are not working and live only on social allowance which is not enough for living. Such situation motivates them for searching the job.

"For example, if my mother dies. Really, one day she will pass away and if I wouldn't get a job and will not get any money, only from state... and if for example my washing machine breaks, I will not have cash money. It is awful" (V interview).

In order to solve such problems persons with epilepsy are trying to get a job and to stay in labour market at any cost.

"When I was looking for a job, I didn't like it. I knew that I needed money because I was renting a flat and needed to pay taxis. I didn't know people there. Anything. It was a very big problem" (III interview).

A job is needed for leading as much as possible regular independent life, for possibility to make social connections, not to stay for all time at home.

"I was sitting at home all my life: home-hospital, home - hospital, home - sanatorium... I wanted to go out to real normal world" (II interview).

Research data also revealed demotivating factors for an employment. Research participants said that in some cases for them it is not financially beneficial to work. They have calculated that minimal salary is smaller than social allowances which persons with epilepsy get if they have defined disability.

"Very recently I was in Labour Exchange office. Everyone is laughing at the situation, people calculated that they get bigger social allowances than salary so they don't want 
to work; my situation is exactly the same. When I told that I have disability and I have restrictions for work, they suggested me to take half-time position and it was very small money. I calculated how much I will spend for travel, and all compensations for heating disappear because I get salary, and I decided not to work. The employment would be absurd for me." (IV interview)

Another demotivating factor is difficulties to find a job which would fit to special needs of persons with epilepsy. A research participant has a profession and could work as a tiler, but there restrictions for work arise:

"Again, how will you carry instruments, you need a car. What car??? It is forbidden by law to have driving license for people with epilepsy" (IV interview).

Earlier employment experiences are painful and demotivating as well

"If I think about my painful employment story... " (IV interview);

"It is one of my most terrible experiences in my life. It is a tragedy when you feel rejected, you feel not important to anybody" (V interview);

"If they are telling that they will call you later, you know - they will never call" (I interview);

"Labour Exchange office gave me a contact to call for cleaner's position. The first question was what kind of disability I have. I asked, what the difference is, if I am looking for a job, it means that I can work" (V interview).

Summarizing this category, it could be said that persons with epilepsy tend to look for a job and stay in labour market because of financial stability and possibility to have social life. However, they face difficulties in finding job which would correspond to their needs. Persons with epilepsy who have disabilities do not have financial motivation to work as they get bigger social allowances than minimal salary. Other demotivating factors such as painful previous employment experience, not adjusted working places or conditions impede wish to have a job.

In the category "Employment experience" the following subcategories were formulated: negative emotions during job interviews, hiding the illness and consequences of it, stress for possible seizure at work.

Research participants talked about negative emotions during job interviews, especially emphasising employers' reaction after illness was discovered.

"If he sees everything in $C V$, if illness has been included, the beginning is still very difficult, he sees that you have illness but choose you. If CV is nice, clean, the most difficult moment comes when you say about illness and see his reaction" (IV interview);

"Sometimes job interview is so tense that you start crying, begging to give a job because you need money, that you need to live, you start telling all story. I have learnt to beg, to humble" (V interview).

Research data showed experience of hiding the illness during job interview and later. Persons with epilepsy know that it is easier to get a job if you do not reveal the fact:

"Yes, I tried. I tried not to tell that I am ill. I decided to work as long as I can. Anyway, I have to work" (I interview).

"They always tell, we have to discuss and we will inform you. And I started to be afraid. If you want a job and you tell about illness, no employee wants to take a risk that something could happen in working place. Then I started to hide. Someone told me to do like that, said that in this case you have a job at least for a while. I have no choice" (III interview).

Hiding the illness becomes like a tool for better adaptation to the reality, however new dilemmas rise:

„Of course, I felt bad. It is important information for an employer, you feel very frustrated and the interviewer feels that. Sometimes they ask 'have you told everything?" (I interview). 
"I had to tell when they sent me to clean staircase. Cold water, you have to go to the basement, nobody is next to you. And I told. I told that I have epilepsy, and that sometimes I have seizure but hope that nothing will happen during the time when I will be cleaning staircase. And nothing has happened. I went cleaning when I felt really well" (I interview).

Epilepsy is episodic, not a visible illness which is easy to hide:

"If I felt worst, I just went away and waited. Don't know for how long. I came back when felt better. But I was working very hard. It was too hard for me. After seizure I felt weak, dizzy. Of course, they notice, were asking, am I ok. I replied that everything is ok" (I interview).

Illness seizures at work make impossible to hide them anymore:

"I was afraid. I was afraid that no one will know how to help me. Then I told that it could happen" (III interview).

The feeling of fear is the most prevailing emotion:

"With this illness you are always in fear. All the time. It is out of control. You wake up, dress yourself, but don't go anywhere because you are afraid of seizure, you always thinkwhat if - and that - what if starts ruling all your life" (V interview);

"I was diagnosed. Oh god, I was afraid to cross the street. It was tremendous fear" (III interview).

Summarizing this category, it could be said that persons with epilepsy feel negative emotions during job interviews. Hiding the illness makes easier to get a job and to stay in it, however, even after illness revealing they fell a permanent fear of seizure, worry that nobody will help them and that employee could fire.

In the category "Relations with employees" these subcategories were formulated: expectations toward employers, stigmatized attitude of employers, stereotypical thinking.

Research participants talked about expectations toward employers. People with epilepsy would like that they would be interested to know more about the illness:

"They have to know the epilepsy, like everyone knows cancer" (V interview).

Also they expect to be accepted as all other people, looking for their capacities and readiness to work:

"Just to look at me like at normal person. Yes, I am ill, but I am controlling the illness, I take medicine. I can work. So, why not take me" (I interview).

Research participants feel stigmatizing attitudes of employers, not willingness to understand, rigidity:

"He made me stop working. He knew that I have a small child and scheduled inconvenient working hours. I signed" (I interview).

Lack of information is one of the reasons for stigmatizing attitudes. Very often epilepsy is understood as psychic illness or mental disability.

"If only an employer knew more. He doesn't know anything and doesn't want to know anything about me. Not even once, he talked with me about the illness" (IV interview);

"They think that epilepsy is a disaster, tragedy, that you are silly, retarded" (V interview).

Summarizing this category, it could be said that persons with epilepsy have clear expectations to employers but meet stereotypical attitudes and discriminating behaviour. Employers lack knowledge and understanding and want to avoid risk at working places.

\section{Conclusions}

Persons with epilepsy are motivated to have a job as they want to have financial stability and richer social life. Job gives possibilities for self-realization, allows feeling better emotionally and physically, provides meaning for the life. However, despite high motivation, persons with epilepsy find difficulties in getting a job or are demotivated by various aspects of 
economic and social systems which do not provide reasonable opportunities to be included in labour market. Job interview is one of the most complicated stages in job seeking. Most of experiences are very painful and force to hide the illness in order to get a job. Hiding the illness has reverse negative consequences for persons with epilepsy as they always feel tension of possibility to have a seizure at work. They also fear that employees sooner or later will know their diagnosis and fire or will start to devaluate their abilities.

Employers are not ready to hire persons with epilepsy as they do not know specifics of the illness and do not give opportunity to start a job and show their capacities. Employers lack knowledge and support from social system in employing and keeping at work places persons with epilepsy. Persons with epilepsy have to know and control their illness and be able to explain individual aspects of the illness to employers during a job interview and later in working process for co-workers. It could help for better inclusion in labour market.

Based on classical sociological theories, people with illness and society members relate such meanings to the illness which support and enforce stigmatized attitude and behaviour towards the person with illness, strengthens negative social aspects of epilepsy, which restrict present and new developed social interactions, and full engagement into society.

\section{References}

[1] LR Socialinès apsaugos ir darbo ministerija, Socialinès integracijos kompleksiniu (integruotu) paslaugu modelio neigaliesiems, sergantiems epilepsija, igyvendinimo 2015-2020 mеtu veiksmu planas (2015)

[2] D. Butvilas, Veiksniai, itakojantys jaunu asmenu, sergančiu epilepsija, gyvenimo visavertiškuma (Kauno medicinos universitetas, 2010)

[3] Tereškinas, J. Bučaitè-Vilkè, Socialinè atskirtis ir geras gyvenimas Lietuvoje (Vilnius: Versus aureus, 2015)

[4] Lietuvos Respublikos Konstitucija (1992)

[5] Neigaliuju teisiu konvencija (Autentiškas vertimas. Ministro Pirmininko tarnybos Organizaciniụ reikalụ valdyba, 2009)

[6] S. Krutulienè,Socialinis darbas 14(1), 53-68 (2016)

[7] P. Šedienè, J. Pivorienè, Socialinis darbas 14(2), 188-198 (2016)

[8] J. Pivorienè, P. Šedienè, Socialinis darbas 16(1), 35-47 (2018)

[9] D. Butvilas, A. Kriščiūnas, M. Endzinienè, G. Jurkevičienè, B. Švedaitè-Sakalauskè, Neurologijos seminarai 14(44), 86-92 (2010)

[10] S. Krutulienè, A. Bagdonas, V. Jakutienè, G. Zdanavičiūtè, Specialusis ugdymas 1(26), 29-44 (2012)

[11] V. Jurkuvėnas, R. Mameniškienè, A Bagdonas, Neurologijos seminarai 17(55), 17-28 (2013)

[12] S. Krutulienė,Socialinis darbas 14(1), 53-68 (2016)

[13] Z. Abramavičiūtè, V. Aleksienè, Acta Pedagogica Vilensia 35, 113-131 (2015)

[14] S. Krutulienè, Socialinis darbas 14(1), 53-68 (2016)

[15] S. Krutuliene, Socialinis darbas 14(1), 53-68 (2016)

[16] P. Šedienè, J. Pivorienè, E. Laskevičiūtè, Eurika, Socialinis darbas: patirtis ir metodai 20(2), 99-115 (2017)

[17] P. Šedienè, J. Pivorienè, Socialinis darbas 14(2), 188-198 (2016)

[18] P. Šediené, Socialinis darbas: patirtis ir metodai 17(1), 117-139 (2016)

[19] A. Baker, Epilepsia 43(6), 26-30 (2002)

[20] A. Jacoby, Epilepsy behav. 3(6S2), 10-20 (2002) 
[21] S. Krutulienè, A. Bagdonas, V. Jakutienè, G. Zdanavičiūtè, Specialusis ugdymas 1(26), 29-44 (2012)

[22] LR Socialinès apsaugos ir darbo ministerija, Socialinès integracijos kompleksiniu (integruotu) paslaugu modelio neigaliesiems, sergantiems epilepsija, igyvendinimo 2015-2020 mеtu veiksmu planas (2015)

[23] P. Smith, S. Wallace, Clinician's guide to epilepsy (Londonas: Arnold, 2001)

[24] A. Baker, Epilepsia 43(6), 26-30 (2002)

[25] S. Krutulienè, A. Bagdonas, V. Jakutienè, G. Zdanavičiūtè, Specialusis ugdymas 1(26), 29-44 (2012)

[26] S. Krutulienè, Socialinis darbas 14(1), 53-68 (2016)

[27] P. Šediené, Socialinis darbas: patirtis ir metodai 17(1), 117-139 (2016)

[28] H. Baier, D. Dennig, M. Geiger-Riess, F. Kerling, U. Specht, R. Thorbecke, MOSES, Moduline epilepsijos mokymo programa. Darbo knyga (Kaunas: Lietuvos Caritas, 2017) 